\title{
DENTAL REMAINS OF IMMATURE INDIVIDUALS OF RHYNCHOTHERIUM BLICKI (FRICK 1933) OF SAN GERARDO DE LIMONCITO, COTO BRUS, COSTA RICA
}

\author{
Ana L. Valerio ${ }^{1} \&$ César A. Laurito ${ }^{2 *}$ \\ ${ }^{1}$ Departamento de Historia Natural, Museo Nacional de Costa Rica \\ Apartado Postal 749-1000; San José, Costa Rica \\ ${ }^{2}$ Instituto Nacional de Aprendizaje \\ Apartado postal 203-2200, Coronado; San José, Costa Rica \\ *Autor para contacto: cesarlaurito@ice.co.cr
}

(Recibido: 15/09/08; aceptado: 12/12/08)

\begin{abstract}
Remains of juvenile individuals of Rhynchotherium blicki (Frick 1933) mastodon have been collected from sediments of the Upper Miocene (Late Hemphillian) locality of San Gerardo de Limoncito, corresponding with the top of Curré Formation. The recovered material, includes two second left upper deciduous molars and three fragments of tusks that were associated to the false gavial Gavialosuchus americanus (Sellards, 1915), remains of a soft shelled turtle Apalone sp., teeth of selachians (sharks and rays) and other icthyolites. The ecological requirements of the taxa suggest the existence of different environmental conditions from open grassland habitats to more closed marine environments like estuaries.

Key words: Gomphotheriidae, Rhynchorostrinae, Upper Miocene, Curré Formation, Costa Rica.

RESUMEN: Restos de individuos inmaduros del mastodonte Rhynchotherium blicki (Frick 1933) fueron colectados en sedimentos de la localidad de San Gerardo de Limoncito de edad Mioceno superior (Hemphilliano tardío), correspondiente al tope la Formación Curré. El material se compone de dos segundos molares deciduos, superiores, izquierdos y tres fragmentos de defensas asociados con restos del falso gavial Gavialosuchus americanus (Sellards, 1915), la tortuga de caparazón blando Apalone sp., dientes de seláceos (tiburones y rayas) y otros ictiolitos. Esta asociación de taxa, sugieren la existencia de diferentes condiciones ambientales que van desde hábitats de sabanas abiertas a ambientes marinos limitados tipo estuario.

Palabras clave: Gomphotheriidae, Rynchorostrinae, Mioceno Superior, Formación Curré, Costa Rica.
\end{abstract}




\section{INTRODUCTION}

Rhynchotherium blicki (Frick, 1933) is considered to be an endemic species of mastodon for Central America. This fossil species is usually found in stratigraphic units from the Upper Miocene of Honduras and El Salvador (Frick, 1933; Olsson \& McGrew, 1941 and Webb \& Perrigo, 1984), relying on uniquely dated isolated finding from Guatemala and Nicaragua (Lucas \& Alvarado, 1995 and Laurito, 1988). It was not until the year 2005 when the authors presented the first $R$. blicki (Frick 1933) finding for Costa Rica. More recently, during the paleontological expeditions of January 2007 and 2008, sponsored by the National Museum of Costa Rica in the locality of San Gerardo de Limoncito, $14 \mathrm{~km}$ to the west of the city of San Vito in the Canton of Coto Brus, province of Puntarenas (geographically positioned at 8 $8^{\circ} 51^{\prime} 19.6^{\prime \prime} \mathrm{N}$ and $83^{\circ} 04^{\prime} 51.9^{\prime \prime} \mathrm{W}$ ), some dental fragments corresponding to immature individuals of $R$. blicki (Frick 1933) were recovered. Study of this scientific finding is presented in this report.

\section{PALEONTOLOGY}

The material recovered consists of two left upper deciduous molars and three fragments of incisors or tusks of small size. These specimens are currently stored in the collection of fossils of the Section of Geology of the Department of Natural History of the National Museum of Costa Rica, under the codes: CFM-2837; CFM-3224; CFM-3361, CFM-3364 and CFM-3365.

Description of fossil CFM-3224: A ${ }^{2} \mathrm{dp}$ or second left upper deciduous molar, bilophodont, with a mesiodistal longitude of the crown measuring $31.84 \mathrm{~mm}$. The crown has two lophs, each one with two cuspids showing advanced stages of wear. The pretrite half loph, which is more worn, especially in posterior loph, corresponds with the lingual trefoil figure and the postrite half loph corresponds with the vestibular oval figure. The anterior loph has a lingual vestibular width of $21.76 \mathrm{~mm}$ and the posterior loph of $25.52 \mathrm{~mm}$. The cusp has a generally inflated aspect or is slightly globose with a maximum height of $15.95 \mathrm{~mm}$ and presents an ample lower ring or cingulum with a width 3.58 $\mathrm{mm}$ (figs. 1a-c).

The specimen CFM-2837: $\mathrm{A}^{2} \mathrm{dp}$, bilophodont, with a medium-distal crown length, measuring $35.35 \mathrm{~mm}$. The crown has two lophs; each one is composed of two cuspids. One is in a worn incipient state. The anterior loph has a vestibularlingual width of $25.39 \mathrm{~mm}$ and contains the main cusp of the crown, measuring $17.13 \mathrm{~mm}$ in height. The posterior loph has a vestibular-lingual width of $30.12 \mathrm{~mm}$. The crown has an inflated aspect, is slightly globose, and has an ample lower cingulum with a width of $5.86 \mathrm{~mm}$. The extreme end of the crown is in worse shape; here there is a short crenulated heel with a series of small cones (figs. $2 \mathrm{a}-\mathrm{c})$. The roots of the tooth are broken with two proximal branches separated, and the two distal branches fused back together.

In both cases, the vestibular half lophs are narrow and elongated, whereas the lingual half lophs or pretrite are wide and round.

Description of CFM-3361: A fragment of relatively large tusk with a length of $54.88 \mathrm{~mm}$, slightly curved and oval in shape. It's major diameter measures $19.40 \mathrm{~mm}$ and the minor diameter is $16.65 \mathrm{~mm}$. It displays an enamel band of 11.14 $\mathrm{mm}$ in width and $2.07 \mathrm{~mm}$ in thickness, the dentine shows longitudinal striae (figs. 3a-b).

The specimen CFM-3364: A fragment of tusk $35.24 \mathrm{~mm}$ in length slightly curved and shows an oval contour. Its major diameter reaches 14.80 $\mathrm{mm}$ and the minor $13.80 \mathrm{~mm}$; it displays an enamel band of $11.01 \mathrm{~mm}$ in width, with a thickness of $4.04 \mathrm{~mm}$ (fig. 4).

The specimen CFM-3365: A small fragment of tusk, of oval contour with a diameter of 15.05 $\mathrm{mm}$; the enamel band has a width of $11.66 \mathrm{~mm}$ and a thickness of $5.42 \mathrm{~mm}$ (fig. 5).

\section{DISCUSSION}

The Rhynchorostrine mastodons are characterized by having a low and extended skull, four tusks; the two upper ones in the pre maxillary 

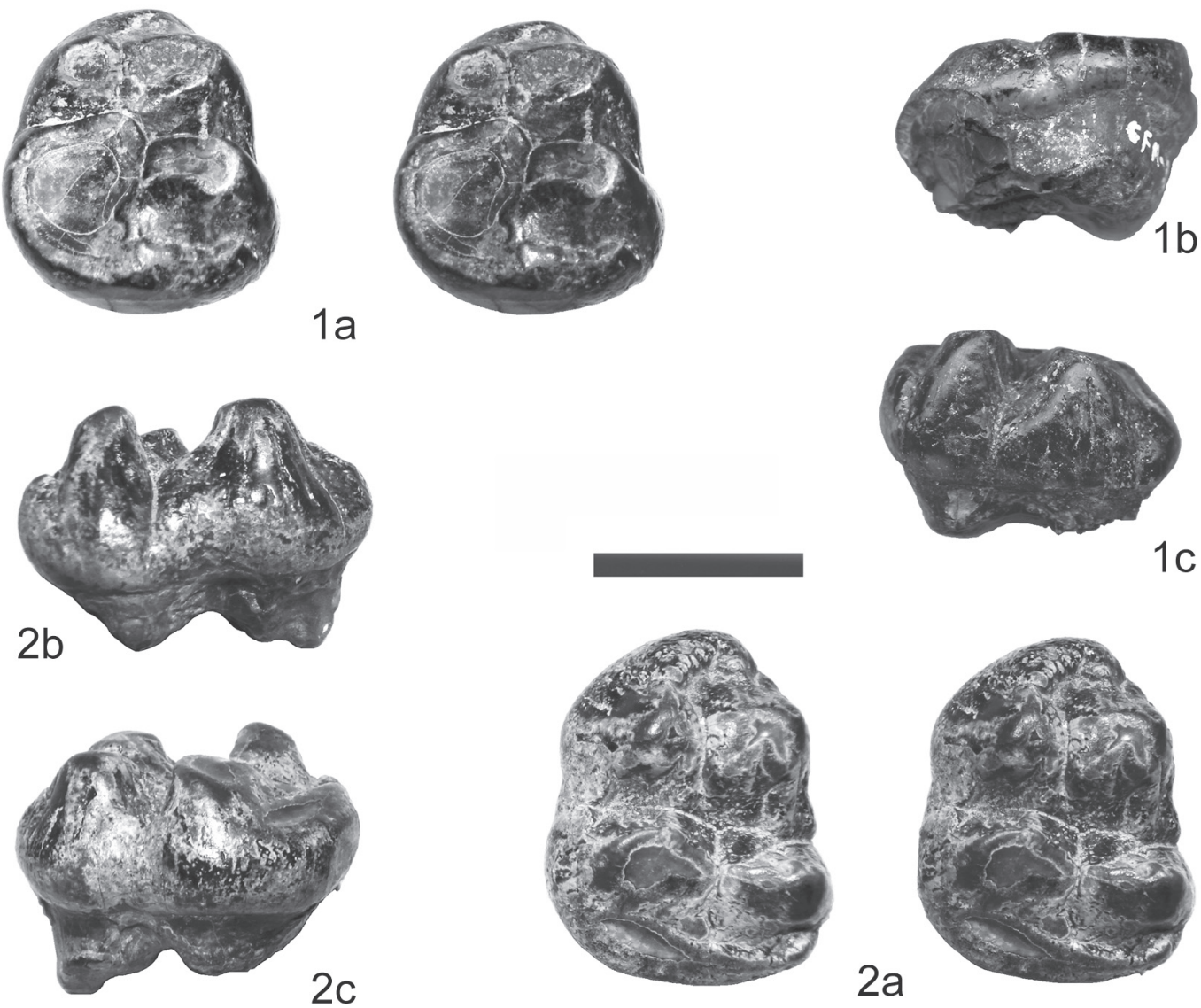

$1 \mathrm{c}$
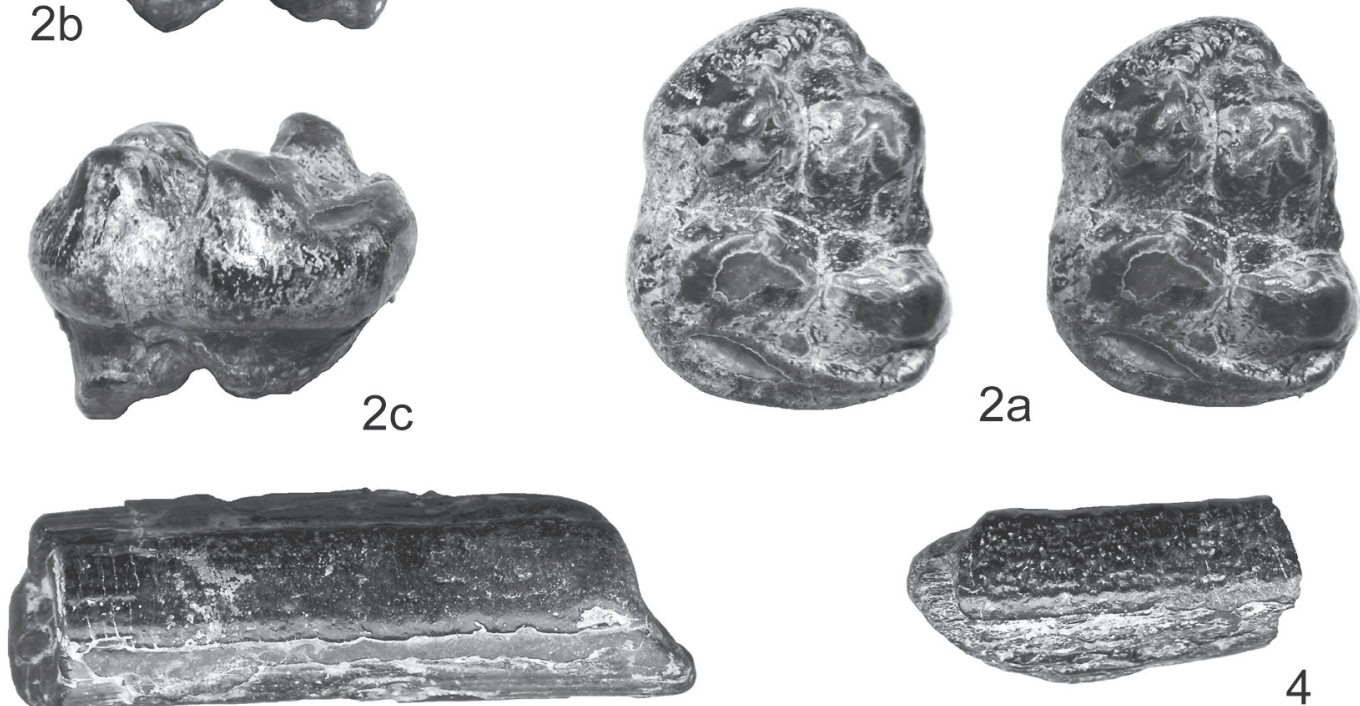

$3 a$

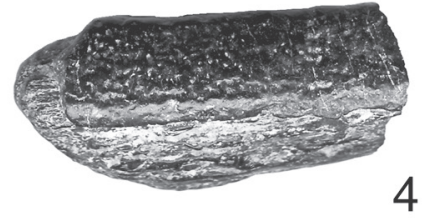

4
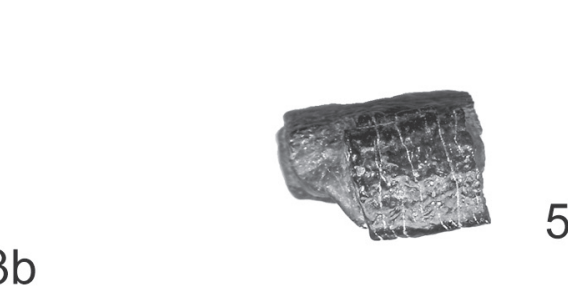

Fig. 1: Dental remains of the mastodon species Rhynchotherium blicki (Frick, 1933). 1. CFM-3224; 2dp in view: a) oclusal (stereographic pair), b) lingual, c) labial; 2. CFM-2837, 2dp in view: a) oclusal (stereographic pair), b) labial, c) lingual; 3. CFM-3361 tusk a) detail of the enamel plate, b) detail of the curvature; 4. CFM-3364 and 5. CFM-3365, fragments of tusk.

Visual scale: $20 \mathrm{~mm}$ 
bone, and the two lower ones, attached to the symphyseal zone of the mandible bones, besides their small height. That small stature is not surprising, because the deciduous molars are very small; their dimensions are approximately 50\% smaller if they are compared with the deciduous molars of other groups of mastodons like the Cuvieronius. The deciduous molars show a bilophodonty characteristic of ${ }^{2} \mathrm{dp}^{2}$ or ${ }^{3} \mathrm{dp}^{3}$. The ${ }^{2} \mathrm{dp}^{2}$ also have a sharpened contour in the distal edge and non-rectangular portion. This makes them different from the ${ }^{3} \mathrm{dp}^{3}$ in Rhynchotherium which are rectangular. This is characteristic of the second upper deciduous molars in the longirostrines and rhynchorostrines mastodons (compare with figures 33 and 37 of Frick, 1933). Furthermore, it is impossible to differentiate between the tusks. The upper tusks look the same as the lower ones because these specimens belong to immature individuals. Additionally, poor development has caused the same curvature, making such differentiation impossible.

Paleobiogeographic distribution, age and paleoecology: This is the second fossil record of the Rhynchotherium blicki (Frick, 1933) for Costa Rica and for southern Central America. This is also the second fossil mastodon evidence found in the Curré Formation. The first fossil came from the locality of San Rita which in agreement with Laurito \& Valerio (2005) belonged to the Formation Paso Real. This was because it was found in a conglomerate located at the top of the Curré Formation and the authors believed that these sediments correspond to continental, non marine sequences. Nevertheless, later evaluations, confirm that the conglomerate from Santa Rita, located $9 \mathrm{~km}$ to the east of the locality of San Gerardo de Limoncito, corresponds to the same unit of conglomerate where the $R$. blicki (Frick 1933) was found. The sedimentology of the conglomerate has been interpreted by the authors (see Laurito \& Valerio, in press a), as a sequence of subaqueous deltaic fan deposits; especially for its common sharks teeth remains.

In addition, the association of $R$. blicki (Frick, 1933) with the false gavial Gavialosuchus americanus (Sellards, 1915) (Laurito \& Valerio, in press a) suggests a late Hemphillian age. Besides, the Pliocene dates of the R. blicki (Frick, 1933) are not reliable because this species is usually found in sediments dating to the Miocene in Guatemala, Honduras, El Salvador and Nicaragua (Frick, 1933; Olson \& McGrew, 1941; Webb and Perrigo, 1984; Lucas and Alvarado, 1995 \& Laurito, 1988).

On the other hand, Webb and Perrigo (1984) postulate a Central American radiation of the genus Rhynchotherium from the early Clarendonian to the early Hemphillian and a reverse dispersal to the north, and Tedford et al., 1987 consider that this genus defines the late Hemphillian faunas of North America.

At last, the record of genus Rhynchotherium suggests a possible warm and humid, savannalike environment (Corona \& Alberdi, 2006) and its distribution in Central America and Mexico during the Hemphillian age, also suggests the existence of a biological corridor along this territory with these environment characteristics.

\section{CONCLUSIONS}

A new locality for the southern Central America with remains of the Rhynchotherium blicki (Frick, 1933) is described, this record, characterized by immature individuals, corresponds to the second find of this species for Costa Rica.

The presence of $R$. blicki (Frick, 1933) associated to the turtle Apalone sp. (Laurito et al., 2005) and the false gavial G. americanus (Sellards, 1915), suggests a late Hemphillian age and a possible warm and humid, savanna-like environment.

The sedimentology of the subaqueous deltaic fan deposits, where the remains come from and were associated, also, with teeth of sharks and rays (Laurito \& Valerio b, this volume), confirms that this sequence corresponds with a transitional environment from marine to continental conditions at the top of the Curré Formation, probably associated to an estuarine environment. 


\section{ACKNOWLEDGMENTS}

Thanks to Galen P. Randall for the translation of this text into English, B.S in Geological Sciences from the University of Arizona.

\section{REFERENCES}

CORONA, E. \& ALBERDI, M.T., 2006: Two new records of Gomphoteriidae (Mammalia Proboscidea) in Southern Mexico and some biogeographic implications.- J. Paleont., 80(2): 357-366.

FRICK, C., 1933: New remains in trilophodonttetrabelodont mastodonts.- American Museum of Natural History Bulletin 59: 505-652.

LAURITO, C.A., 1988: Los proboscidios fósiles de Costa Rica y su contexto en la América Central.- Vínculos 14(1-2): 29-58.

LAURITO, C.A. \& VALERIO, A.L., 2005: First Record of Rhynchotherium blicki (Frick, 1933) for the Late Cenozoic of Costa Rica.Rev. Geol. Amér. Central, 33: 75-82.

LAURITO, C.A. \& VALERIO, A.L., this volume: The first record of Gavialosuchus americanus Sellards (1915) (Eusuchia: Crocodylidae, Tomistominae) for the Late Tertiary of Costa Rica and Central América.- Rev. Geol. Amér. Central.

LAURITO, C.A. \& VALERIO, A.L. b, this volume: Ictiofauna de la localidad de San Gerardo de Limoncito, Formación Curré,
Mioceno Superior, cantón de Coto Brus, provincia de Puntarenas, Costa Rica- Rev. Geol. Amér. Central.

LAURITO, C.A., VALERIO, A.L., GÓMEZ, L.D., MEAD, J.I., PÉREZ, E.A. \& PÉREZ, L.G., 2005: A Trionichidae (Reptilia: Testudines, Cryptodira) from the Pliocene of Costa Rica, Southern Central America. Rev. Geol. Amér. Central, 32:7-11.

LUCAS, S.G. \& ALVARADO, G.E., 1995: El proboscidio Rhynchotherium blicki (Mioceno Tardío) del Oriente de Guatemala.- Rev. Geol. Amér. Central, 18: 19-24.

OLSON, E.C. \& MCGREW, P.O., 1941: Mammalian fauna from the Pliocene of Honduras.- Bull. Geol. Soc. of America 52: $1219-1244$.

TEDFORD, R. H., M. F. SKINNER, R. W. FIELDS, J. M. RENSBERGER, D. P. WHISTLER, T. GALUSHA, B. E. TAYLOR, J. R. MACDONALD, \& S. D. WEBB. 1987: Faunal succession and biochronology of the Arikareean through Hemphillian interval (late Oligocene through earliest Pliocene epochs) in North America, p. 153-210. In M. O. Woodburne (ed.), Cenozoic Mammals of North America: Geochronology and Biostratigraphy. University of California Press, Berkeley.

WEBB, S.D. \& PERRIGO, S.C., 1984: Late Cenozoic vertebrates from Honduras and El Salvador.- Journal of Vertebrate Paleontology, 4(2): 237-254. 